\title{
Carter v. Canada: What's next for physicians?
}

\author{
Jocelyn Downie SJD
}

$\mathrm{O}$ n Feb. 6, 2015, the Supreme Court of Canada unanimously declared that the Criminal Code prohibitions on physician-assisted dying (both assisted suicide and voluntary euthanasia) violate the Canadian Charter of Rights and Freedoms. ${ }^{1}$ The Court immediately suspended the declaration, which means that its decision does not come into effect for 12 months. Canadians therefore have a year to prepare for the reality of legal physician-assisted dying, assuming that the federal government does not invoke the notwithstanding clause. In the immediate aftermath of this decision, a key question for physicians is "what can and should physicians do over the coming months to help the country get ready?" Indeed, there is much that physicians can do to help to ensure that Canada will be able to go forward with a legal framework that protects the vulnerable, enables competent adults to exercise their autonomy when their suffering becomes too much to bear and reconciles the competing charter rights of life, liberty and security of the person (patients) and conscience (physicians).

First, however, physicians must enter the implementation design phase with a very clear sense of what the Court said. In sum, physicianassisted dying includes both assisted suicide and voluntary euthanasia. ${ }^{1,2}$ Access is limited to assistance provided by physicians to competent adults who have a grievous condition (including illness, disease or disability) that cannot be alleviated by means acceptable to the person and causes enduring physical or psychological suffering that is intolerable to the individual in the circumstances of his or her condition. Physicianassisted dying is not for children or patients who are otherwise not competent (either through an advance directive or substitute decision-maker). Assisted dying is permitted only with the free and informed consent of the individual.

Physicians will be key contributors to public discussions concerning outstanding procedural and substantive questions. The Court struck down legislation - it did not (and could not) design a regulatory framework for the new permissive regime. Thus, the procedural safeguards that must be followed remain to be seen. For example, must two physicians be involved? How many days must pass between a request for assistance being made and the assistance being provided? Will institutions be permitted to refuse to provide physician-assisted dying? Substantive questions also remain. Will access be permitted beyond that which was delineated by the Court? Will physician-assisted dying be permitted through advance directives for individuals with dementia? Will it be permitted for mature minors? Physicians have a crucial role in the conversation on these issues as subject matter experts. However, they also need to recognize when others have relevant knowledge and that the voice of the physician should therefore be but one among many. In addition, it will be helpful for physicians to address the questions not only from the perspective of the system in which they want to work but also the system in which they would want to be a patient.

Contemporary medicine prides itself on being evidence-based. Physicians are well situated to insist on and support evidence-based policies, procedures and practices. They can speak to the need for reliable empirical evidence to support arguments for particular policies, procedures and practices. In addition, physicians must play a part in designing and implementing the longitudinal research needed to inform policy, procedure and practice on an ongoing basis in Canada - this should be done quickly so as to lay a foundation of good baseline data. Lessons can be learned from other jurisdictions (e.g., the Netherlands and Oregon) that have decades of experience with such data gathering and analysis. ${ }^{3,4}$

\begin{abstract}
Competing interests: Jocelyn Downie is a member of the Royal Society of Canada Expert Panel: End-of-Life Decision Making and was a member of the pro bono legal team representing Carter et al. in Carter v. Canada (Attorney General).
\end{abstract}

This article has been peer reviewed.

Correspondence to: Jocelyn Downie, jocelyn.downie@dal.ca

CMAJ 2015. DOI:10.1503 /cmaj.150202 
As a self-regulating profession, physicians sometimes resist reporting requirements and balk at external oversight. This resistance is, at least in some circumstances, understandable. Some policy-makers may hesitate to introduce a robust oversight system for assisted dying for fear of antagonizing the medical community. However, this is a time to set aside traditional dislikes and distrust. For the system to earn and deserve the trust of Canadians, physicians need to embrace reporting requirements to, and oversight by, an independent national or provincial body (depending on what level of government ends up regulating assisted dying). ${ }^{5}$

In the longer term, human resources will be a key issue. How can we ensure that there are physicians willing and able to provide assisted dying once it is legal and regulated? Physicians, new and experienced, will need to learn both how to deliver assisted dying according to regulations and how to work with patients and their loved ones, as well as other members of the health care team, in the lead up to an assisted death. Much may be learned from the experience of others, particularly from those specialties with years of experience in end-of-life care (e.g., palliative care) and jurisdictions with experience in physician-assisted dying. ${ }^{3,4}$

The issue of conscientious objection will also need to be resolved. The Court was clear that its decision would not compel any physicians to provide assisted dying. However, the Court also recognized that respecting conscientious objection comes at a cost - lowering access to an intervention that is not contrary to law or the policy of the Canadian Medical Association. ${ }^{6}$ With respect to conscientious objection, clear guidance regarding referrals and the provision of assisted dying for a patient who requests it must be established. Physicians will need to engage with legislators and colleges on the issue of a duty to refer. ${ }^{7}$

Physicians must stand up both for those physicians who object to assisted dying and for patients. One way to do this is to establish and support a network of physicians prepared to step in when a patient wants access to assisted dying but who either has a physician who is a conscientious objector or does not have access to a consulting physician (as will likely be required under the law). Such a network could also provide information and support for physicians providing assisted dying. ${ }^{8}$
With the government's attention keenly focused on end-of-life law and policy, there is a singular opportunity for physicians to advocate for the expansion of palliative care. Quebec and Belgium are excellent examples of governments being persuaded to explicitly tie the opening up of access to physician-assisted dying to increased access to palliative care. ${ }^{5,9}$ Canada has some excellent palliative care services, but they must be made more widely available. Physicians could usefully bring concrete recommendations for improving access to quality palliative care to the attention of lawmakers as they are focused on assisted dying. ${ }^{10,11}$

As a result of the Court's decision in Carter v. Canada (Attorney General), the medical profession has much to do in the next 12 months. Physicians have an extraordinary opportunity to have a tremendously positive impact on end-oflife care in Canada.

\section{References}

1. Carter v. Canada (Attorney General), 2015 Supreme Court of Canada 5. Available: https://scc-csc.lexum.com/scc-csc/scc -csc/en/item/14637/index.do (accessed 2015 Feb. 16)

2. Downie J. The Supreme Court of Canada decision allows for the prescription and the syringe. Available: http://impactethics. $\mathrm{ca} / 2015 / 03 / 01 /$ the-supreme-court-of-canada-decision-allows-for -the-prescription-and-the-syringe/ (accessed 2015 Mar. 3).

3. Jaarverslagen voorgaande jaren [in Dutch]. Arnhem (The Netherlands): Regionale toetsingcommissies euthanasia; 2012. Available: www.euthanasiecommissie.nl/archiefjaarverslagen.asp (accessed 2015 Feb. 16).

4. Death with Dignity Act. Portland (Oregon): Oregon Health Authority; 2014. Available: http://public.health.oregon.gov /ProviderPartnerResources/EvaluationResearch/DeathwithDignity Act/Pages/index.aspx (accessed 2015 Feb. 16).

5. An Act respecting end-of-life care, RSQ c S-32.0001. Quebec National Assembly; 2015. Available: www.canlii.org/en/qc/laws /stat/rsq-c-s-32.0001/latest/rsq-c-s-32.0001.html (accessed 2015 Feb. 16)

6. Canadian Medical Association. Euthanasia and assisted death (update 2014). Ottawa: Canadian Medical Association; 2014 Available: www.cma.ca/Assets/assets-library/document/en /advocacy/EOL/CMA_Policy_Euthanasia_Assisted\%20Death PD15-02-e.pdf (accessed 2015 Mar. 3).

7. Professional Obligations and Human Rights. The College of Physicians and Surgeons of Canada; 1990. Available: http://policyconsult .cpso.on.ca/wp-content/uploads/2014/12/Draft-Professional -Obligations-and-Human-Rights.pdf (accessed 2015 Feb. 16)

8. Van Wesemael Y, Cohen J, Onwuteaka-Philipsen BC, et al. Establishing specialized health services for professional consultation in euthanasia: experiences in the Netherlands and Belgium. BMC Health Serv Res 2009;9:220.

9. Law on Palliative Care. Brussels (Belgium): Ministere des Affaires Sociales, de la Sante Publique et de l'Environnement; 2002 Available: www.soinspalliatifs.be/images/pdf/loi_2002 06 14.pdf (accessed 2015 Feb. 16)

10. Palliative care. Toronto: Ministry of Health and Long-Term Care; 2014. Available: www.auditor.on.ca/en/reports_en /en14/308en14.pdf (accessed 2015 Feb. 16).

11. End-of-Life Health Care in Ontario: OHTAC Recommendation. Toronto (ON): Health Quality Ontario; 2014. Available: www .hqontario.ca/Portals/0/Documents/eds/ohtas/recommendation-eol -1411-en.pdf (accessed 2015 Feb. 16).

Affiliation: Faculties of Law and Medicine, Dalhousie University, Halifax, NS 